Slobodan Cvetanović, $\mathrm{PhD}^{1}$

SCIENTIFIC REVIEW ARTICLE

University of Niš, Faculty of Economics,

Received: January 25, 2015

Danijela Despotovic, $\mathrm{PhD}^{2}$

Accepted: February 19, 2015

University of Kragujevac, Faculty of Economics

Milorad Filipović, $\mathrm{PhD}^{3}$

University of Belgrade, Faculty of Economics

\title{
THE CONCEPT OF SOCIAL CAPITAL IN ECONOMIC THEORY
}

\begin{abstract}
Economic research at the turn of the century has been explicitly dealing with the social capital, as a special form of capital. It is a relatively new concept, which is why it is not surprising that there is no generally accepted term to denote this phenomenon. The social capital means the economic benefit of the society, which can be reached with the help of communication, cooperation, and trust among the entities in the given socio-economic environment. The social capital is most often regarded as the ability of social structures and attitudes that support them to increase the effectiveness of collective action. The social capital is a connective tissue, a glue that helps people to use available resources for creating mutual benefits. Its existence is a prerequisite for economic growth and development. The components of the social capital are social ties and networks that can be transformed into economic capital.
\end{abstract}

Key words: capital, social capital, physical capital, natural capital, human capital

JEL classification: J24, O35

\section{КОНЦЕПТ ДРУШТВЕНОГ КАПИТАЛА У ЕКОНОМСКОЈ ТЕОРИЈИ}

\begin{abstract}
Апстракт
Крајем претходног и почетком овога века у економским истраживањима све се дециидније говори о друштвеном капиталу, као посебном облику капитала. Ради се о релативно новом кониепту и стога није чудно што не постоји опште прихваћено појмовно одређење овог феномена. Друштвени капитал означава економску корист друитва до које се долази захваљујући комуницираюу, сарадњи и поверењу између појединих субјеката у посматраној друштвеноекономској средини. Најчешће се о друштвеном капиталу говори као о способности друштвених структура, и ставова који их подржавају, да повећају
\end{abstract}

\footnotetext{
${ }^{1}$ slobodan.cvetanovic@eknfak.ni.ac.rs;

2 ddespotovic@kg.ac.rs;

3 miloradf@eunet.rs
} 
ефикасност колективне акиије. Друштвени капитал је везивно ткиво, лепак који помаже људима да расположиве ресурсе ставе у функиију унапрећења заједничке користи. Његово постојање је предуслов привредног раста и развоја. Компоненте друштвеног капитала су друитвене везе и мреже које је могуће трансформисати у економски капитал.

Кључне речи: капитал, друштвени капитал, физички капитал, природни капитал, људски капитал

\section{Types of capital in economics}

Some economic theorists imply different concepts when considering capital. The capital often refers to money and various forms of securities, and sometimes to physical assets that are used for further reproduction (machinery and equipment, buildings, inventories). In recent times, capital has been increasingly connected with natural resources which individual countries have.

Samuelson and Nordhaus believe that capital is one of the three main factors of production (in addition to land and labour), and that it is made of manufactured goods that are re-used as production inputs for further production (Samuelson \& Nordhaus, 2014). In this regard, they see capital in terms of its physical form, i.e. they take into account capital goods which include infrastructure. According to them, capital goods have features of production inputs, but also of final production outputs.

Mankiw identifies capital with stocks of equipment and structures that are used to produce goods and services (Mankiw, 2012). This theorist believes that the key feature of the capital is that it is a produced factor of production.

In presenting his ideas regarding the concept of sustainable development, Robert Solow sees production factors as involving, in addition to labour, the natural capital, i.e. natural resources, and the work-produced capital, which includes: a) physical capital (buildings, equipment, machinery, etc.) created through investment, b) human capital in the form of acquired knowledge and experience, with which individuals participate in the production processes, and c) intellectual capital, as the scientific, technical, and, in the broadest sense, cultural resource which human society at a given time has (Solow, 1986).

A number of studies make a distinction between capital that is a "gift of nature", i.e. natural reality, and forms of capital derived from the stock of accumulated and creative activities of human beings (Drašković, 1998).

The founder of the theory of social capital, Bourdieu, makes a distinction between three types of capital: economic, social, and cultural-symbolic (Bourdieu, 1972; 1986). Economic capital is characterised by the power of direct conversion into money, and is institutionalised in the form of property rights.

Coleman, as undoubtedly one of the leading authorities in the previously mentioned theory of the social capital, also distinguishes among three types of capital: physical (the capacity to develop tools and production), human capital (the capacity to develop knowledge and skills of individuals), and social capital in terms of the capacity to involve individuals in social ties (Coleman, 1988; 1994). Physical capital refers to 
physical objects, the human capital to attributes of individuals, and social capital to links between individuals, i.e. social networks and the norms of reciprocity and trustworthiness that arise from them.

During the last decade of the previous century, the concept of capital in the economic literature has been, in terms of categorisation, significantly expanded. In fact, decades-long dominant opinion, according to which capital includes only visible resources, has been modified, to expand its scope to intangible resources, such as human and social capital. Unlike physical capital, which is completely tangible, and expressed in the visible material forms, human capital, expressed in the skills and knowledge acquired by individuals, is less tangible, and social capital, which exists only in the relationships between people, is the least tangible (Cvetanović \& Despotović, 2014). Quite a number of authors, however, extend the complex of capital, by including many other forms, such as institutional, organisational, cultural capital, and so on.

Increase in each of the above-listed forms of capital requires the time needed to create and maintain the capital, and to directly and indirectly contribute to economic growth. From the standpoint of economic growth of the country, it is necessary to view capital as a collection of physical, human, financial, and other resources required for production. This approach makes it possible to better understand how different forms of capital are combined in order to achieve results, and how these same resources can be substituted or complemented.

Figure 1: Types of capital

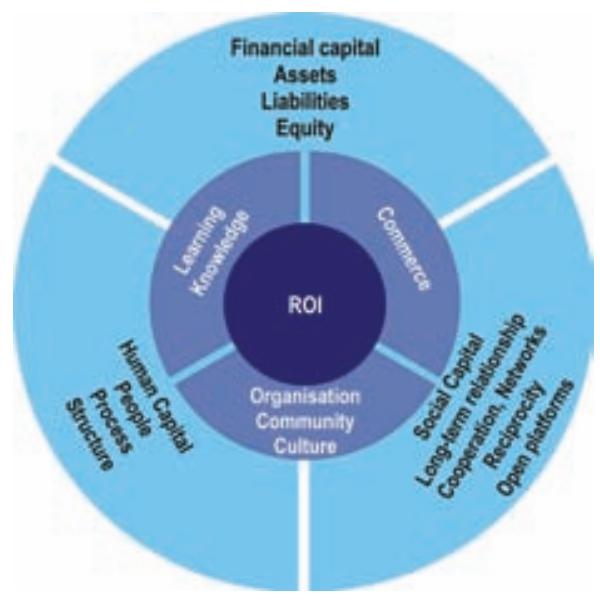

The classification of capital into physical, natural, human, social, and financial capital has a special importance and suggests complexity of the research into the ways and methods of its quantitative increase and qualitative improvement (Figure 1). Regardless of the form of capital, it is important that it: a) contributes to the production of goods and services, i.e. economic growth and development, b) brings profit, and c) represents input in the process of creating economic value (Cvetanović \& Mladenović, 2013). 


\section{The content and elements of social capital}

The social capital is the capital of cooperation, joint action, mutual trust, and mutual assistance, which are formed in the course of economic relations between individuals. It cannot be privately owned and has the attributes of a public good. It is not directly observable because people carry it inside. Different environments support different forms of social capital, resulting in their different economic evaluation.

Economists find the origin of the concept of social capital in the work of Adam Smith, particularly bearing in mind his analysis of the importance of the division and specialisation of labour (Smith, 1776). In his work, Smith emphasises the importance of personal freedom in the creation of wealth of individual nations, claiming that the virtues of individuals are not necessary for the efficient functioning of the economy as a whole. Since individuals continually express the desire to maximise their usefulness, distrust necessarily becomes the basic postulate in analysing the behaviour of individuals as economic agents.

Social capital consists of institutions, relationships, attitudes, and values that govern interpersonal interactions and contribute to the wider economic and social development. It is largely the result of the legal, political, and institutional environment, in which economic actors operate, i.e. perform their functions and realise objectives. It is the capital of permanent, and, to some degree, institutionalised relations between individuals and organisations, which facilitate activities and contribute to the creation of economic value.

The literature presents views on the basis of which only participation in formal organisations makes social capital. However, there are also diametrically opposed reflections and opinions, according to which even sporadic participation in social movements is a component of social capital.

Coleman, one of the creators of the theory of social capital, analyses this complex through its functions (Coleman, 1988; 1994). He states that social capital allows individual successes since individuals derive benefit from it. It is a special form of public good that is potentially available to everyone involved in the system of social ties and relationships.

According to Putnam, social capital consists of social attributes, such as trust, norms, as well as the most diverse networks that can improve social efficiency through coordinated action (Putnam, 1993; 1995). Relations between people have a value and potential for development, both for individuals, who are involved in many social ties, as well as for groups and the entire community. Putnam makes a distinction between bonding and bridging social capital. Bonding social capital represents the power of relations, in which people express concern and support each other (similarity by gender, age, ethnicity, race). Bridging social capital designs relations between different social groups, allowing individuals to acquire certain skills outside their usual group.

At the end of the last century, the World Bank made a significant contribution to the development of research studies and the promotion of the concept of social capital in the field of economics. The World Bank defines social capital as the institutions, relationships, attitudes, and values that govern interactions among people and contribute to economic and social development. Social capital refers to the presence of trust, norms, and social networks that enable social action for the benefit of both individuals and 
society as a whole. Stocks of social capital in society are proportional to the number of social networks and intensity of social relations (World Bank, 1998).

The most important elements of social capital are social networks, social norms, trust, and reciprocity. These elements enable people to achieve a synergistic effect through joint action and the creation of various business partnerships. In other words, it relates to the characteristics of social organisations, such as networks, norms, and trust, which facilitate coordination and cooperation in order to arrive at a common benefit. "Social ties and relationships, which form the basis of social capital, open up opportunities for access to different resources. Resources that can be created with the help of various social ties are diverse: information, ideas, business opportunities, recommendations, advice, capital, etc." (Golubović, 2007, p. 164).

Lin suggests a model, as an initial step in the theoretical consideration of social capital. As seen in Figure 2, the model includes three blocks of variables in the causal sequences (see bottom of the picture). One block represents the prerequisites and precursors of social capital: factors in the social structure and the position of each individual in the social structure that can facilitate or limit the investment of social capital. The second block represents the elements of social capital, and the third block represents possible reverse effects of social capital (Lin, 1999).

Figure 2 - The elements of social capital

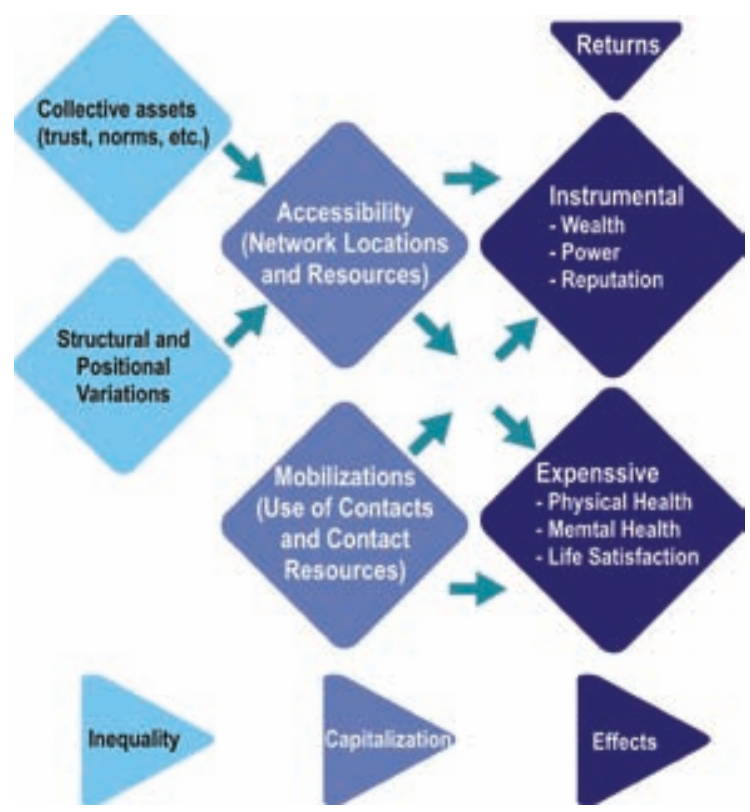

Source:modified according to Lin, 1999

Literature sees human and social capital as intangible forms of capital. Both types of capital are developed in close interdependence. Increase in human capital significantly corresponds with the development of social capital. At the same time, social capital is an important and indispensable factor in creating and increasing the efficiency of human 
capital. Moreover, there are many authors that see certain attributes of social capital as the components of human capital.

The fact is that each production activity involves social, in addition to physical and human capital. Social capital is linked to groups, not individuals. Associating with other individuals allows collective action. Through various organisations, associations, social networks, etc. individuals gain experience of cooperation, establish personal contacts, and generate interest, which cannot be achieved solely by individual action. This component of capital is associated with trust and reciprocity.

Some forms of human capital (knowledge of chemistry and physics, for example) can be used for destructive purposes (production of nuclear bombs, terrorism), while others can have extremely negative social consequences. The negative consequences of social capital include various forms of nepotism, corruption, organised crime, ethnocentricity, etc.

The three most common forms of social capital are: structural, relational, and cognitive social capital. Although these forms of social capital support each other, they can also exist independently from each other.

Structural social capital consists of various networks, associations, and institutions, as well as the rules and procedures they establish. Relational social capital indicates the quality of connectedness. Cognitive social capital consists of attitudes and behavioural norms, shared values, trust, and reciprocity.

\section{Social networks}

Networks are a component of social life, and they allow stakeholders to efficiently access the realisation of a large number of common goals. Based on an almost unanimous opinion of researchers, they represent an important precondition for the creation of social capital (Stokman, 2004; Barr, 1988).

The process of creating social ties is an important feature of the concept of social capital. Individuals acquire social capital by participating in informal networks, registered organisations, various associations, as well as numerous social movements.

Social capital is actually created, maintained, and increased by the core features of social life, formal and informal, horizontal and vertical network of relationships among individuals, the norms that regulate them, and established relationships of trust that allow individuals to work together more effectively in the realisation of common objectives. Membership in different organisations provides opportunities for individuals to develop common interests and adopt common norms, resulting in a higher level of trust and understanding among people. By participating in numerous networks and relationships, individuals increase their chances of realising certain rights or benefits in a more efficient way.

Social capital refers to ties within and between social networks. Social networks have a value that expands opportunities for the growth of productivity through human capital (at individual and collective levels) and achievement of fulfillment of individuals.

It is possible to distinguish a number of different social networks. On the one hand, there are personal networks and networks of enterprises, with participants in the immediate environment; in this regard, relationships, although occasionally commercial, 
tend to be informal and casual. On the other hand, local production systems are a special type of network, formed on the basis of physical and commercial relations, predominantly based on trust.

The network can be defined as a system of relationships and/or contacts that connect companies and participants, and whose contents may be related to material goods, information, and technology. From the aspect of economic activity, the network is a set of relationships between companies and entrepreneurs, which facilitates the exchange of goods, services, and information. The concept of network refers to transactions in terms of reciprocity. In addition, the concept of network includes independent relationships among participants and companies.

Networks are related to systems of multiple interconnections and the responses and reactions of firms and individuals. They are characterised by a series of weak ties, whose interaction strengthens the network, through access to information, interactive learning, and diffusion of innovation. Relations between the companies and the participants may be asymmetrical, with the hierarchical nature, when power becomes a functional element of network performance. They can be formal, when they are explicitly associated with decisions concerning the strategic goals of individuals and organisations. However, they can also be informal, i.e. of spontaneous or tacit nature. The former refer to the relations among individuals and organisations such as banks and service companies, while the latter refer to their interaction with family members, friends, work colleagues, etc. Networks between firms can also apply to commercial transactions, i.e. to the exchange of goods and services, which facilitate relations with suppliers and customers.

The presence in networks increases the chances of achieving certain goals. In this regard, informal networks involve contacts with family, neighbours, colleagues, and friends who may belong to the same or a different generation, status, or national and confessional groups. Formal networks of connections involve the presence and activity in political and civil society organisations. As a rule, simultaneous presence of several organisations strengthens the network of connections and increases social capital.

Based on a narrower view of social capital, this complex includes the creation of horizontal connections between people, which consist of social networks, and their respective norms, affecting the economic and social development. Social ties can increase productivity, by reducing the cost of certain economic activities.

In the economy, networks appear as informal ties (institutions) in the already formed formal relations, which complement, enrich, and strengthen existing ties and relationships. The most important features of the network in the economy are related to trust, responsibility, and accuracy.

Entrepreneurial network is a personal and business network formed by entrepreneurs in order to realise their entrepreneurial venture. It includes ideas, instructions, business opportunities, easier access to financial capital, trust, cooperation, power, influence. At the stage of generating ideas and starting a business, an entrepreneur is focused on personal networks of family members, relatives, and friends. After that, the entrepreneur creates formal business networks, and social capital becomes an integral component of their organisational competence.

Participation in networks and organisations is important, but this alone does not produce trust. For example, a high level of trust in the Scandinavian countries is associated with a pronounced ethnic homogeneity of the population, the fact that the majority of 
people are Protestants, and the circumstance that these countries are characterised by extremely egalitarian distribution of wealth (Hyggen, 2006).

\section{Trust}

Increasing complexity and uncertainty of the business environment has led, at the end of the previous millennium, to prominent interest of economists, sociologists, and psychologists in the concept of trust. The research rarely defines the content of the category of trust clearly and unambiguously.

Trust is one of the most important elements of all business transactions. In the economic literature, access to trust is mainly based on the observation and analysis of models of relations between the seller and the buyer, which exhibit the effect of several variables associated with trust, as its prerequisites, or its outcomes.

The English language uses two different terms to denote this concept: confidence and trust. The first term refers more to guarantees, insurance, and self-esteem, while the latter expresses the idea of ties and relationships. For example, at the first contact with a firm, the consumer will look for some form of guarantee, in order to establish a one-off or lasting relationship with this company. Once the relationship is established, the satisfaction regarding experienced positive experience comes into play. Thus, for example, a new product, launched under the brand with which a customer has always been satisfied, enjoys already created capital of trust.

The existence of a high level of trust is of essential importance for economic activity, and beyond, for social and political stability. Trust, in this case, goes beyond the scope of the family or wider kinship loyalty. It means readiness to cooperate with unknown individuals within the social community. Trust presupposes the existence of common views on social relationships and a sense of the common good.

Willingness to comply with the norms depends on how other people behave in a society, and what that kind of behaviour brings to individuals. In environments that are characterised by widespread disrespect of key norms (especially the norms of reciprocity), collective action, based on cooperation, is, as a rule, inefficient.

Trust reduces unnecessary costs in economic relations and promotes the effectiveness of a political system. Trust is an important requirement for the functioning of society, but it is also a very important resource for individuals. Of great importance is the question of whether mutual trust exists at the level of small social groups (family, closed organisations, etc.), or it spreads to all levels of the community as a whole. Countries that have a high radius of trust at the same time have a significant level of social capital, which is a prerequisite for economic prosperity. Economic activities that rely on future actions of individual agents are realised at lower costs, if implemented in an environment that is characterised by a high level of trust. Conversely, a low level of trust among economic agents will result in higher costs and correspondingly lower economic efficiency. Any commercial transaction implies the existence of a certain level of trust. Areas with a low overall level of trust lag behind others in terms of economic development. Simply put, lack of trust affects the growth of price of some economic transactions, whether it is about negotiating, the implementation of sales contracts, or monitoring. In contrast, in societies characterised by a high level of trust, economic 
agents use less resources to protect their assets in economic transactions. In them, written contracts are less necessary and less detailed. Societies that are characterised by a low level of trust among agents, as a rule, have unfavourable innovation climate. By directing available resources to the protection of property rights, prevention of fraud by employees, business partners, and the government, entrepreneurs are left with less funds to realise activities associated with finding new products, improving existing products, and increasing productivity and economic efficiency.

The societies with a high level of trust are less dependent on formal institutions dealing with the protection of property rights and contracts. In additions, in societies where formal institutions are underdeveloped, high level of trust among transactors has a positive effect on the volume of economic transactions and is a good substitute for underdeveloped or inefficient government institutions. In a society with a high level of trust, credibility of the state administration is higher, which has a positive effect on investment and economic activities. Furthermore, a high level of trust in the society does not only have a positive effect on the accumulation of physical capital, but also has a particular influence on the maximisation of human capital. In these societies, knowledge and labour market is much more developed. In contrast, in societies with a low level of trust, employment decisions are much more based on connections and corruption, than on objective criteria of ability, as is the case in societies with a high level of trust.

The existence of a system of values and norms shared by most members of society does not imply the existence of social capital. The system of values and norms may be such that it fully or partially impedes cooperation among members of society. The most commonly used example of the society with a strong system of norms, but with no social capital that enables and encourages cooperation among members of society, is the south of Italy. Mafia organisation is characterised by pronounced internal code of conduct, omerta. The norms of conduct that apply within the organisation, do not apply beyond.

In recent times, the concept of trust has often been replaced by the category of reciprocity. Trust has a tendency to cause trust, while distrust tends to cause distrust. This reliability in a certain way "lubricates social life", by causing the kind of interaction that supports the norms of reciprocity, as a kind of foundation stone of social capital.

\section{Social capital and economic activity}

The positive influence of the state on the development of social capital is manifested through the implementation of a number of public policies. This, first of all, refers to how certain resources can lead to better results in achieving higher levels of social cohesion, trust, and commitment. Examples generally involve reforms in the education system, the promotion of social capital in the community, the affirmation of art and culture, as well as the commitment to the introduction of more flexible working hours, which would allow greater scope of common contacts of people in the family and the local community.

Social capital is not only found in the local communities that share the same values and norms, but is also very developed at the regional level, which is likely to maintain the high intensity of interaction (Agirre et al., 2009). In a globalising world with more complexity and competitive pressures, the regions endowed with this social capital lower operating costs and meet the growing need for coordination between more specialised firms (Figure 3). 
Figure 3: The economic potential of social capital

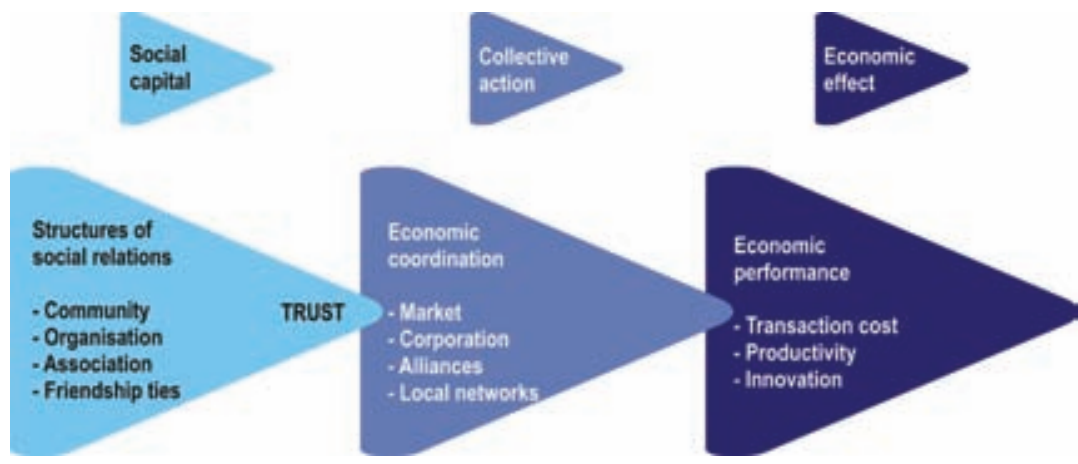

Source: modified according to Agirre et al., 2009

More and more studies show that various forms of social capital are an important determinant of economic growth and development, and that distrust is an important constraint to economic growth and development. As a form of collective self-help, social capital is particularly important for the underdeveloped and poor communities.

Some features of social capital are similar to other types of capital. First, its increase implies certain investments, if not always in monetary form, then always in the form of time and labour. Second, social capital plays a role in the creation of economic value. It significantly increases the efficiency of transmission of knowledge and skills from one to the other parts of the organisation, or from one environment to another. The economic function of social capital is reflected in the reduction of transaction costs related to the mechanisms of formal harmonisation, such as: contracts, hierarchies, bureaucratic rules. No contract can foresee every detail that may arise between the parties.

The impact of social capital is manifested through dense business networks that foster economic cooperation and build trust between economic agents. Social capital created in the enterprise and between enterprises significantly reduces the risk and uncertainty of business. It enables the exchange of valuable information about products and markets, and reduces the costs of contracting, regulation, and enforced collection. When it comes to economic development, it is possible to monitor the impact of social capital on the public and private sector, trade, territorial mobility of workforce, reduction of inequality in income distribution. Stable and equitable financial system is a prerequisite for sustainable growth. Social capital has an impact on both formal and informal financial system.

The market model abstracts the honesty of agents. Trust in a person is acquired based on knowledge of their preferences, skills, possible options, and their consequences. In the long term, there is an extremely important element related to trust, reputation or business standing.

On the other hand, social capital can have significant negative economic effects. The spread of corruption channels and ties, and even politicisation of crime and criminalisation, are illustrative examples of possible negative aspects of social capital.

Finally, it should be noted that some authors challenge the use of the complex designated as social capital in the context of impact on economic growth and development. 
For example, Kenneth Arrow believes that in the case of social capital, there are no material investments, which per se means that, from an economic point of view, there is no justification to treat it as a factor of economic growth. Robert Solow holds a very similar view, calling into question the use of the concept, particularly quantification of social capital.

\section{Conclusion}

Social capital supports economic development, primarily by enabling transactions among individuals, households, and groups. Participation of individuals in social networks increases the availability of information and reduces their cost. An example of such information is information about the prices of certain products on the market, the emergence of new markets, financial resources, new jobs, the reliability of a particular dealer, etc. Participation in local networks and mutual trust allow certain social groups to make decisions and implement collective action.

\section{References}

Agirre, A., Lizarralde, I., Altuna Erle, R., \& Grellier, H. (2009). Building up an innovation region through cooperative experiences. Pôle Sud, 31(2), 71-86.

Barr, A. (1998). Enterprise Performance and the Functional Diversity of Social Capital, Center for the Study of African Economies, Oxford University, Oxford, June.

Bourdieu, P. (1972). Outline of a Theory of Practice, Cambridge University Press, Cambridge.

Bourdieu, P. (1986). The Forms of Capital, Handbook of Theory and Research for the Sociology of Education, Richardson J. (ed.), Greenwood, New York, pp. 241-248.

Coleman, J. (1988) Social Capital in the Creation of Human Capital, American Journal of Sociology, 94/Supplement, pp. 95-120.

Coleman, J. (1994) Foundations of Social Theory, Belknap Press, Cambridge, MA.

Cvetanović, S. Despotović, D. (2014) Knowledge as the component of human capital in economic growth models, Škola biznisa, 1, pp. 1-17

Cvetanović, S. Mladenović, I. (2013) Ekonomija kapitala i finansiranje razvoja, Niš: izdanje autora.

Drašković, B. (1988) Ekonomija prirodnog kapitala, Institut ekonomskih nauka, Beograd.

Gates, B., Myhrvold, N., \& Rinearson, P. (1995). The road ahead.

Golubović, N. (2007) Društveni kapital, Ekonomski fakultet, Niš, 2007.

Hyggen, C. (2006) Risks and Resources: Social Capital among Social Assistance Recipients in Norway, Social Policy \& Administration 5, pp. 493-508.

Lin, N. (1999). Building a network theory of social capital. Connections, 22(1), 28-51.

Mankiw, G. (2012) Principles of Macroeconomics, Mason: South-Western. 
Putnam, R. (1995), Bowling Alone: America's Declining Social Capital, Jornal of Democracy, No. 61, pp. 65-78.

Putnam, R. et. al. (1993), Making Democracy Work: Civic Traditions in Modern Italy, Princeton. University Press, Princeton.

Samuelson, P. Nordhaus, W. (2014) Economics, McGraw Hill.

Smith, A. (1776) An Inquiry into the Nature and Causes of the Wealth of Nations (1 ed.). London: W. Strahan.

Solow, R. (1986) On the Intertemporal Allocation of Natural Resources, Scandinavian Journal of Economics 88, pp. 141-149.

Stokman, F. N. (2004). Frame dependent modeling of influence processes.RationalChoice-Theorie in den Sozialwissenschaften. Anwendungen und Probleme, 113-127

World Bank (1998) Assesing Aid: What Works, What doesn't and Why, Oxford University Press, New York. 